GLOBAL JOURNAL OF ENGINEERING RESEARCH VOL 14, 2015: 1-7

COPYRIGHTC BACHUDO SCIENCE CO. LTD PRINTED IN NIGERIA. ISSN 1596-292x

\title{
COMPRESSIVE AND FLEXURAL STRENGTH OF CEMENT MORTAR STABILIZED WITH RAFFIA PALM FRUIT PEEL (RPEP)
}

I. M. AHO AND E. E. NDUBUBA

(Received 11 August 2015; Revision Accepted 21 September 2015)

\begin{abstract}
Mortar is a material with wide range of applications in the construction industry. However, plain mortar matrices are usually brittle and often cracks and fails more suddenly than reinforced mortars. In this study, the compressive and flexural strengths of cement mortar stabilized with Raffia Palm Fruit Peel (RPFP) as fibre were determined. The cement-sand mortars were in the ratios of $1: 1$ and $1: 2$ respectively. They were stabilized with $2 \%, 4 \%, 6 \%$ and $8 \%$ RPFP fibres respectively by volume using a water cement ratio of 0.5 . Test cubes and beams measuring $150 \times 150 \times 150 \mathrm{~mm}$ and $160 \times 40 \times 40 \mathrm{~mm}$ were cast and subjected to cube and central point loading crushing tests respectively. Density measurements were also taken. The compressive strength of test specimens were found to reduce with increases in RPFP fibre while the flexural strength increased with increase in the fibre content. The average compressive strength after 28 days of curing was $10.67 \mathrm{~N} / \mathrm{mm}^{2}$ at $8 \%$ stabilization for the $1: 1$ mix and $10.01 \mathrm{~N} / \mathrm{mm}^{2}$ at the same percentage stabilization for $1: 2 \mathrm{mix}$ ratio. Also the average flexural strengths (i.e. Modulus of Rupture) were $4.26 \mathrm{~N} / \mathrm{mm}^{2}$ and $4.29 \mathrm{~N} / \mathrm{mm}^{2}$ respectively for the two mix ratios at the same fibre percent and curing period. The densities decreased with increase of fibre content. The results compare well with similar tests on mortars stabilized with coir, rice husk and sawdust. The results confirm that fibre stabilized mortars could be used as light-load bearing members in civil engineering constructions.
\end{abstract}

KEYWORDS: Mortar, Raffia Palm Fruit Peel (RPFP), Fibre, Modulus of Rupture, Compressive Strength.

\section{INTRODUCTION}

Mortar is one of the most widely used structural materials, as it can offer good performance for bedding unit masonry, plastering and with the addition of coarse aggregates for concrete. However, plain mortar materials are usually brittle and often crack more easily and fail more suddenly than reinforced or stabilized mortars. In the same vein, cement-based matrices are becoming more expensive because of the rising cost of cement, which has also affected the conventional roofing sheets and tiles.

The introduction of fibres as stabilizers to cement mortars is expected to ameliorate these problems. This is because fibres are light, cheap, affordable and possess properties that place them at advantage over plain mortar when combined with mortar at optimum percentage or volume ratio, these include higher tensile and impact strength, higher elastic modulus, better sound proofness and lower thermal conductivity (Ndububa, 2000).

The properties of some natural fibres have been studied by several investigators including Mattone (1990). Some of those found to be of use as stabilizing material includes the fibres from elephant grass, sisal, coconut-coir, sugarcane baggase, saw dust and asbestos. Dahunsi (2000) reported that cement matrices

I. M. Aho, Department of Civil Engineering, University of Agriculture, Makurdi, Nigeria.

E. E. Ndububa, Department of Civil Engineering, University of Abuja, Abuja, Nigeria. 
reinforced with natural materials have been adapted to various uses such as construction of reservoirs, pipes, floors and covers. The Raffia Palm Fruit Peel (RPFP) is the outer layer of hard, glossy, imbricate reddish - brown scales covering the large avoid fruits of the raffia palm tree (Raphis Famifera). The fruits are as big as hen's egg with a single hard nut. The rhomboid triangular and apex - beaked peels are arranged in overlapping vertical rows on the fruits each with a median grove. The RPFP reported in this paper were sourced from Benue State of Nigeria. The local people tap raffia palm wine from the tree stem and use the leaves for roofing and fencing.

According to Cabrera and Nwaubani (1990), fibres assist in arresting plastic and initial drying shrinkages cracks and limit the propagation of micro cracks when concrete is subjected to tensile loading.

This study investigated the compressive and flexural properties of RPFP and evaluated its potential as a stabilizing material to improve the performance of mortar in both wet and hardened states.

\subsection{MATERIALS AND METHODS}

\subsection{Preparation of Materials}

The fruits were air-dried for 96 hours and later cooked in a large metal pot for 2 hours. The cooking softened the fruits and facilitated easy removal of the hard scaly outer peel layer used as the RPFP fibre.

Un-compacted bulk density of the RPFP was determined by filling up a cylinder of known weight and volume with it. The weight of container and sample was recorded and bulk density calculated as the weight of RPFP per volume of the cylinder. The moisture content of RPFP samples was evaluated by measuring the weights of fibre samples in its wet and oven dry states respectively. The moisture content was calculated as the ratio of the amount of water present in samples to its oven - dried weight.

\subsection{Mixing, Casting and Compaction}

Batching of sand and cement was by volume in the ratios of $1: 1$ and 1:2. The cement was first mixed thoroughly dry with sand before fibre was introduced to the dry mixes in the percent quantities of $2 \%, 4 \%, 6 \%$ and $8 \%$ by volume of the dry matrix respectively of the matrices. These were thoroughly mixed again before water was introduced. A water/cement ratio of 0.5 was maintained. The mixing continued until a workable mix was achieved.

The formworks for the test cubes and beams were adequately lubricated before casting. In accordance with ASTM specification, the wet samples were placed in three layers each and compacted in three rounds of four strokes each. Five samples were prepared for the respective mortars for testing (minimum of three is allowed by ASTM). Toweling was done to smoothen the surface and remove excess materials.

\subsection{Curing}

The specimens were cured by wet sac and water sprinkling under laboratory conditions. The atmospheric temperature ranged between 20 and $32^{\circ} \mathrm{C}$. Curing was done for 28 days before testing was carried out.

\section{$2.4 \quad$ Testing}

Test beams and cubes measuring $160 \times 40 \times$ $40 \mathrm{~mm}$ and $150 \times 150 \times 150 \mathrm{~mm}$ respectively and having $1: 1$ and 1:2 mix proportions were tested. The flexural strength of the beams at 28 days were determined using central point loading in accordance with the requirements of BS 1881: part 118 (1983). Similarly test cubes were crushed to evaluate the compressive strength of test samples as prescribed by BS 1881: part 119 (1983).

\subsection{RESULTS AND DISCUSSIONS}

The moisture content of air - dried RPFP samples were found to range between $6 \%$ and $16 \%$. The average moisture content was $12.8 \%$. The moisture content of the fibre may have an effect on the strength properties of mortar as some of the water needed for the production of a workable mortar mix may be absorbed by unsaturated RPFP.

The compressive strength of RPFP stabilized mortar was found to reduce with further increment in the percentage of stabilization as shown in Table 1 and 2, and figure 1 and 2. This could be attributed to the increase in void spaces with increasing volume of RPFP in the mortar. Modulus of Rupture is a measure of the Flexural Strength. It was observed to have increased with increase in RPFP fibre content as presented in Table 3 and 4, and Figure 3 and 4 respectively. The results also show that plain mortar possessed higher strengths, however the failure modes for the plain samples were sharp and 
sudden, and exhibiting considerable brittleness. It is observed that the $1: 1$ and $1: 2$ mortars as stabilized with RPFP fibres did not show any significant differences in both compressive and flexural strength results, thereby conferring an economic advantage to the 1:2 mix over the 1:1 mix. From Table 3 and 4 the densities decreased with increase of fibre content. At $8 \%$ for the $1: 1$ mix and, $6 \%$ and $8 \%$ for the $1: 2$ matrix the densities recorded lower values below $1800 \mathrm{Kg} / \mathrm{mm}^{3}$ thereby passing for light-weight structural materials at this levels.
An earlier report by Ndububa (2000) on mortars stabilized with vegetable fibres confirmed their suitability as alternative materials in lightweight constructions particularly in roofing sheets, tiles and partition walls. In comparative terms, mortar stabilized with RPFP fibre possesses higher compressive and flexural strengths over those stabilized with coir, rice husk and sawdust as given in the same report. This might be due to the higher compressive and tensile strength of RPFP fibres over the others.

Table 1: Compressive Strength of 28-day 1:1 mix Mortar Stabilized with RPFP

\begin{tabular}{|c|c|c|c|c|}
\hline Beam Ref. No. & $\%$ of RPFP & $\begin{array}{l}\text { Crushing load } \\
(\mathrm{KN})\end{array}$ & $\begin{array}{l}\text { Compressive } \\
\text { strength }\left(\mathrm{N} / \mathrm{mm}^{2}\right)\end{array}$ & $\begin{array}{l}\text { Average } \\
\text { compressive } \\
\text { strength }\left(\mathrm{N} / \mathrm{mm}^{2}\right)\end{array}$ \\
\hline $\begin{array}{l}\text { A1 } \\
\text { A2 } \\
\text { A3 } \\
\text { A4 }\end{array}$ & 0 & $\begin{array}{l}575 \\
480 \\
565 \\
655 \\
\end{array}$ & $\begin{array}{l}25.56 \\
21.33 \\
25.11 \\
29.11\end{array}$ & 25.28 \\
\hline $\begin{array}{l}\text { B1 } \\
\text { B2 } \\
\text { B3 } \\
\text { B4 }\end{array}$ & 2 & $\begin{array}{l}300 \\
285 \\
290 \\
230\end{array}$ & $\begin{array}{l}13.33 \\
12.67 \\
12.89 \\
10.22\end{array}$ & 12.28 \\
\hline $\begin{array}{l}\text { C1 } \\
\text { C2 } \\
\text { C3 } \\
\text { C4 }\end{array}$ & 4 & $\begin{array}{l}325 \\
265 \\
235 \\
260\end{array}$ & $\begin{array}{l}14.44 \\
11.78 \\
10.44 \\
11.56\end{array}$ & 12.06 \\
\hline $\begin{array}{l}\text { D1 } \\
\text { D2 } \\
\text { D3 } \\
\text { D4 }\end{array}$ & 6 & $\begin{array}{l}265 \\
240 \\
315 \\
245 \\
\end{array}$ & $\begin{array}{l}11.78 \\
10.67 \\
14.00 \\
10.89 \\
\end{array}$ & 11.78 \\
\hline $\begin{array}{l}\text { E1 } \\
\text { E2 } \\
\text { E3 } \\
\text { E4 }\end{array}$ & 8 & $\begin{array}{l}255 \\
160 \\
295 \\
250 \\
\end{array}$ & $\begin{array}{l}11.33 \\
7.11 \\
13.11 \\
11.11\end{array}$ & 10.67 \\
\hline
\end{tabular}


I. M. AHO AND E. E. NDUBUBA

Table 2: Compressive Strength of 28 - day 1:2 mix Mortar Stabilized with RPFP

\begin{tabular}{|c|c|c|c|c|}
\hline Beam Ref. No. & $\%$ of RPFP & Crushing load (KN) & $\begin{array}{l}\text { Compressive } \\
\text { strength }\left(\mathrm{N} / \mathrm{mm}^{2}\right)\end{array}$ & $\begin{array}{l}\text { Average } \quad \text { compressive } \\
\text { strength }\left(\mathrm{N} / \mathrm{mm}^{2}\right)\end{array}$ \\
\hline $\begin{array}{l}\text { F1 } \\
\text { F2 } \\
\text { F3 } \\
\text { F4 }\end{array}$ & 0 & $\begin{array}{l}517.5 \\
501 \\
538 \\
524\end{array}$ & $\begin{array}{l}23.01 \\
22.71 \\
23.90 \\
23.30\end{array}$ & 23.23 \\
\hline $\begin{array}{l}\text { G1 } \\
\text { G2 } \\
\text { G3 } \\
\text { G4 }\end{array}$ & 2 & $\begin{array}{l}360 \\
300 \\
335 \\
310\end{array}$ & $\begin{array}{l}16.00 \\
13.33 \\
14.89 \\
13.78 \\
\end{array}$ & 14.5 \\
\hline $\begin{array}{l}\mathrm{H} 1 \\
\mathrm{H} 2 \\
\mathrm{H} 3 \\
\mathrm{H} 4\end{array}$ & 4 & $\begin{array}{l}310.5 \\
270.5 \\
250.5 \\
220.5\end{array}$ & $\begin{array}{l}13.8 \\
12.02 \\
11.13 \\
9.8 \\
\end{array}$ & 11.69 \\
\hline $\begin{array}{l}\mathrm{J} 1 \\
\mathrm{~J} 2 \\
\mathrm{~J} 3 \\
\mathrm{~J} 4\end{array}$ & 6 & $\begin{array}{l}230 \\
235 \\
325 \\
230 \\
\end{array}$ & $\begin{array}{l}10.22 \\
10.44 \\
14.44 \\
10.22 \\
\end{array}$ & 11.33 \\
\hline $\begin{array}{l}\text { K1 } \\
\text { K2 } \\
\text { K3 } \\
\text { K4 }\end{array}$ & 8 & $\begin{array}{l}205 \\
215 \\
246 \\
235\end{array}$ & $\begin{array}{l}9.11 \\
9.56 \\
10.93 \\
10.44 \\
\end{array}$ & 10.01 \\
\hline
\end{tabular}

Table 3: Flexural Strength of 28 - day 1:1 mix Mortar Stabilized with RPFP

\begin{tabular}{|c|c|c|c|c|c|c|}
\hline $\begin{array}{l}\text { Beam Ref. } \\
\text { No. }\end{array}$ & $\%$ of RPFP & $\begin{array}{l}\text { Overweight } \\
\text { of sample } \\
(\mathrm{Kg})\end{array}$ & $\begin{array}{l}\text { Load at } \\
\text { failure }(\mathrm{N})\end{array}$ & $\begin{array}{l}\text { Density of } \\
\text { sample } \\
\left(\mathrm{Kg} / \mathrm{mm}^{3}\right)\end{array}$ & $\begin{array}{l}\text { Modulus of } \\
\text { Rupture } \\
\left(\mathrm{N} / \mathrm{mm}^{2}\right)\end{array}$ & $\begin{array}{l}\text { Ave. Modulus of } \\
\text { Rupture }\left(\mathrm{N} / \mathrm{mm}^{2}\right)\end{array}$ \\
\hline $\begin{array}{l}\text { A1 } \\
\text { A2 } \\
\text { A3 } \\
\text { A4 } \\
\text { A5 }\end{array}$ & 0 & 0.547 & $\begin{array}{l}2060 \\
2205 \\
2380 \\
2175 \\
2375\end{array}$ & 2137 & $\begin{array}{l}5.55 \\
5.51 \\
5.95 \\
5.44 \\
5.94\end{array}$ & 5.6 \\
\hline $\begin{array}{l}\text { B1 } \\
\text { B2 } \\
\text { B3 } \\
\text { B4 } \\
\text { B5 }\end{array}$ & 2 & 0.502 & $\begin{array}{l}1575 \\
1250 \\
1425 \\
1450\end{array}$ & 1960 & $\begin{array}{l}3.94 \\
3.13 \\
3.56 \\
3.63\end{array}$ & 2.85 \\
\hline $\begin{array}{l}\text { C1 } \\
\text { C2 } \\
\text { C3 } \\
\text { C4 } \\
\text { C5 }\end{array}$ & 4 & 0.486 & $\begin{array}{l}1140 \\
1450 \\
1820 \\
1800 \\
1600\end{array}$ & 1896 & $\begin{array}{l}2.85 \\
3.63 \\
4.55 \\
4.50 \\
4.00\end{array}$ & 3.96 \\
\hline $\begin{array}{l}\text { D1 } \\
\text { D2 } \\
\text { D3 } \\
\text { D4 } \\
\text { D5 }\end{array}$ & 6 & 0.471 & $\begin{array}{l}1760 \\
1760 \\
1640 \\
1635 \\
1635\end{array}$ & 1840 & $\begin{array}{l}4.40 \\
4.40 \\
4.10 \\
4.09 \\
3.39\end{array}$ & 4.08 \\
\hline $\begin{array}{l}\text { E1 } \\
\text { E2 } \\
\text { E3 } \\
\text { E4 } \\
\text { E5 }\end{array}$ & 8 & 0.455 & $\begin{array}{l}1530 \\
2070 \\
1335 \\
1875 \\
1700\end{array}$ & 1777 & $\begin{array}{l}3.83 \\
5.18 \\
3.34 \\
4.69 \\
4.25\end{array}$ & 4.26 \\
\hline
\end{tabular}


Table 4: Flexural Strength of 28 - day 1:2 mix Mortar Stabilized with RPFP

\begin{tabular}{|c|c|c|c|c|c|c|}
\hline $\begin{array}{l}\text { Beam Ref. } \\
\text { No. }\end{array}$ & $\%$ of RPFP & $\begin{array}{l}\text { Overweight } \\
\text { of sample } \\
(\mathrm{Kg})\end{array}$ & $\begin{array}{l}\text { Load at } \\
\text { failure }(\mathrm{N})\end{array}$ & $\begin{array}{l}\text { Density of } \\
\text { sample } \\
\left(\mathrm{Kg} / \mathrm{mm}^{3}\right)\end{array}$ & $\begin{array}{l}\text { Modulus of } \\
\text { Rupture } \\
\text { (N/mm }{ }^{2} \text { ) }\end{array}$ & $\begin{array}{l}\text { Ave. } \\
\text { Modulus of } \\
\text { Rupture } \\
\left(\mathrm{N} / \mathrm{mm}^{2}\right)\end{array}$ \\
\hline $\begin{array}{l}\text { F1 } \\
\text { F2 } \\
\text { F3 } \\
\text { F4 }\end{array}$ & 0 & 0.516 & $\begin{array}{l}1625 \\
1905 \\
1725 \\
1850\end{array}$ & 2015 & $\begin{array}{l}4.06 \\
4.76 \\
4.31 \\
4.63\end{array}$ & 4.44 \\
\hline $\begin{array}{l}\text { G1 } \\
\text { G2 } \\
\text { G3 } \\
\text { G4 } \\
\text { G5 } \\
\end{array}$ & 2 & 0.490 & $\begin{array}{l}1225 \\
1300 \\
860 \\
1500 \\
1345\end{array}$ & 1914 & $\begin{array}{l}3.06 \\
3.25 \\
2.15 \\
3.75 \\
3.36 \\
\end{array}$ & 3.11 \\
\hline $\begin{array}{l}\mathrm{H} 1 \\
\mathrm{H} 2 \\
\mathrm{H} 3 \\
\mathrm{H} 4 \\
\mathrm{H} 5\end{array}$ & 4 & 0.470 & $\begin{array}{l}1530 \\
1370 \\
1260 \\
1275 \\
1475 \\
\end{array}$ & 1836 & $\begin{array}{l}3.83 \\
3.43 \\
3.15 \\
3.19 \\
3.69 \\
\end{array}$ & 3.46 \\
\hline $\begin{array}{l}\mathrm{J} 1 \\
\mathrm{~J} 2 \\
\mathrm{~J} 3 \\
\mathrm{~J} 4 \\
\mathrm{~J} 5\end{array}$ & 6 & 0.459 & $\begin{array}{l}1770 \\
1750 \\
1780 \\
1510 \\
1800\end{array}$ & 1793 & $\begin{array}{l}4.43 \\
4.38 \\
3.95 \\
3.78 \\
4.50\end{array}$ & 4.20 \\
\hline $\begin{array}{l}\text { K1 } \\
\text { K2 } \\
\text { K3 } \\
\text { K4 } \\
\text { K5 } \\
\end{array}$ & 8 & 0.442 & $\begin{array}{l}1680 \\
1960 \\
1570 \\
1550 \\
1720 \\
\end{array}$ & 1727 & $\begin{array}{l}4.20 \\
4.90 \\
4.20 \\
3.93 \\
4.22 \\
\end{array}$ & 4.29 \\
\hline
\end{tabular}

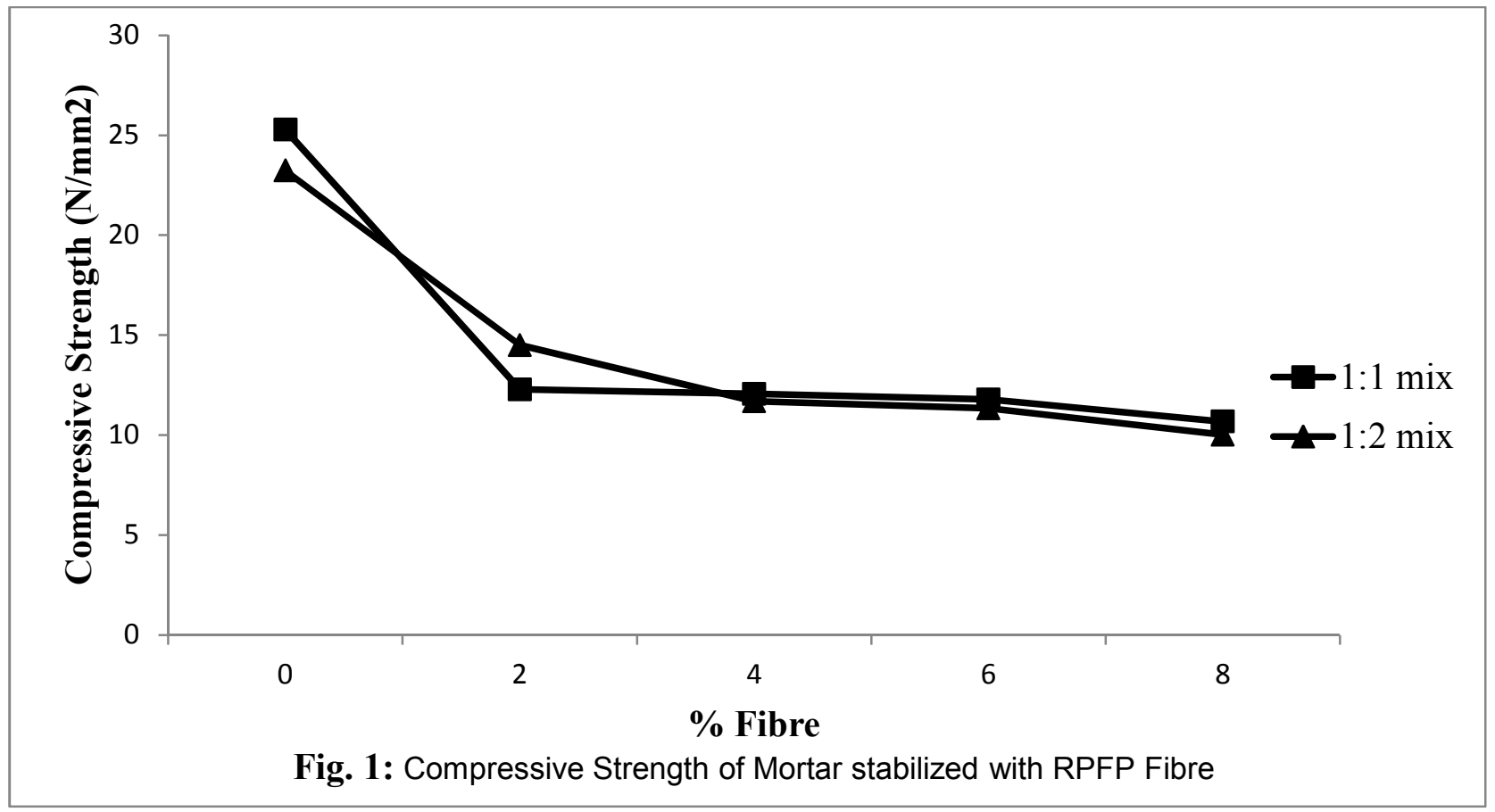




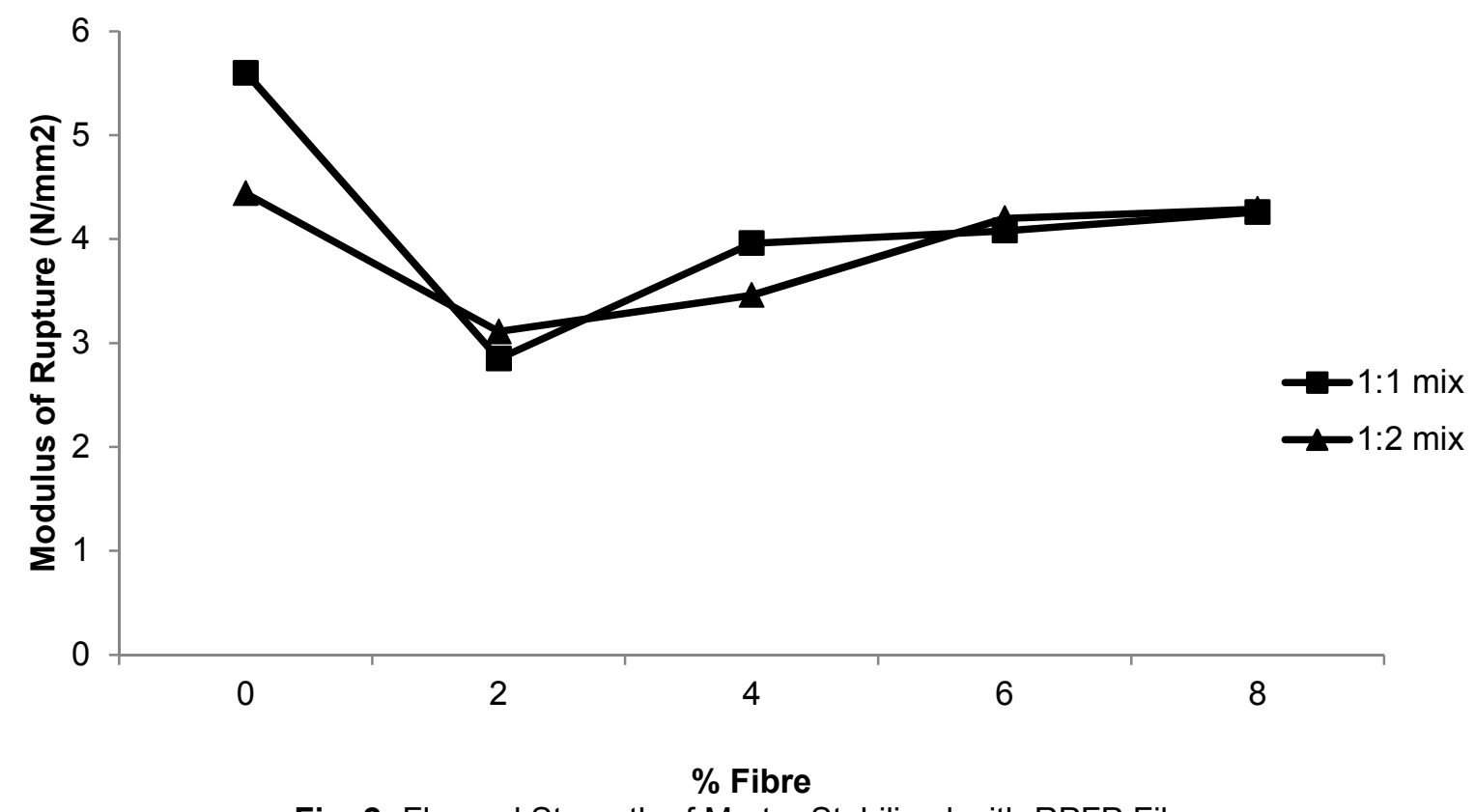

Fig. 2: Flexural Strength of Mortar Stabilized with RPFP Fibre

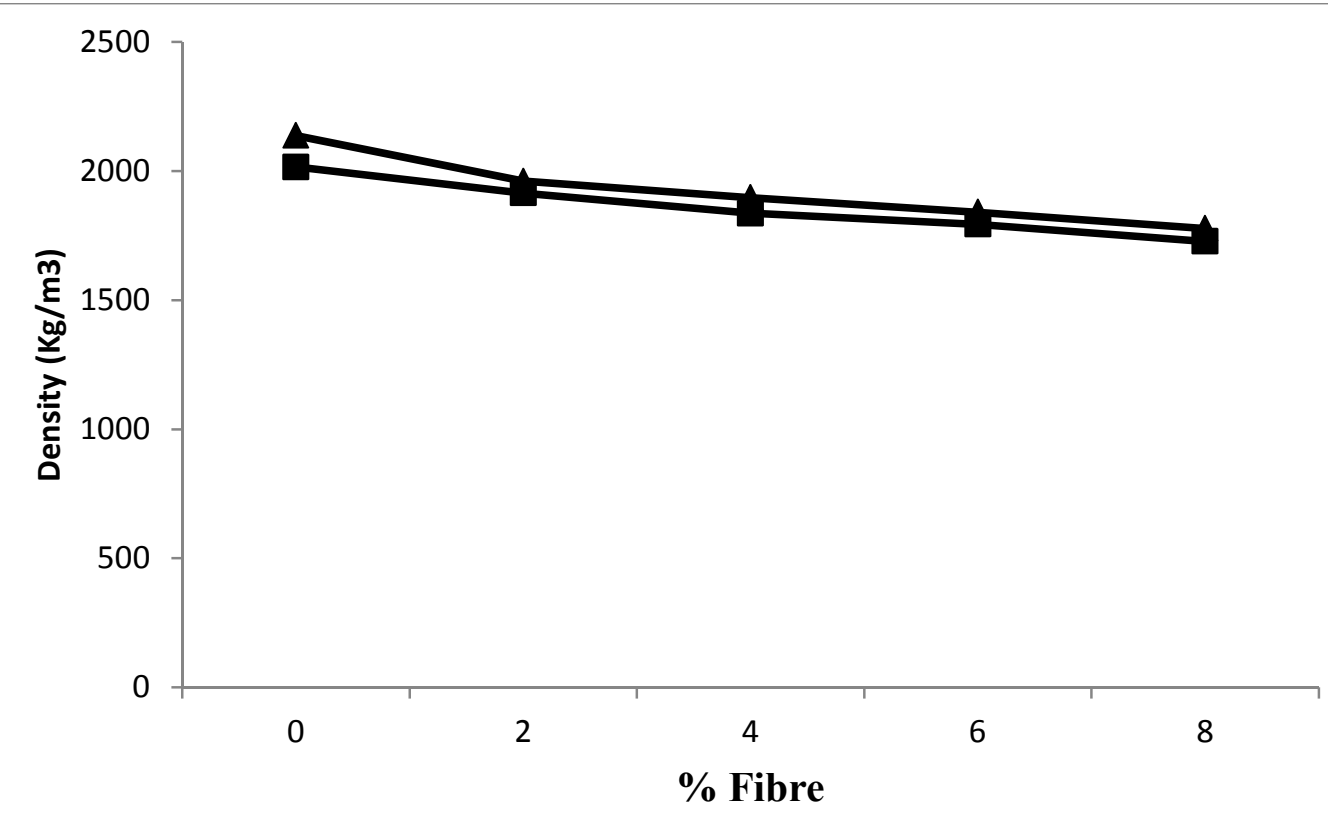

$\rightarrow-1: 1 \mathrm{mix}$

$\rightarrow-1: 2 \operatorname{mix}$

Fig. 3: Density of Mortar Stabilized with RPFP Fibre 


\section{CONCLUSION}

From this study, the effects of raffia palm fruit peel as a mortar stabilizing agent have been presented. It could be concluded that reinforcing mortar beams with raffia palm fruit peel fibres improved the flexural strength but resulted in reduction of compressive strength at percentage composition of RPFP of $4 \%$ and above. The flexural and compressive strengths of RPFP stabilized mortar were adequate enough for the construction of light-weight structural elements.

The most important applications of fibre mortar could be in the production of roofing sheets, ceiling sheets, tiles and partition walls.

\section{REFERENCES}

American Society for Testing and Materials: Standard Test Method for Flexural Strength of Hydraulic Cement Mortars. ANS/ASTMC 348-80, Philadelphia pp. 241-245.

British Standard Institute., 1983. BS 1881: part 118 Method for Determination of Flexural Strength BSI, London.

British Standards Institute., 1983. BS 1881: Part 119, Method for Determination of Compressive Strength. BSI, London.
Cabrera, J. G and Nwaubani, S. O., 1990. Experimental Methods for the Preparation of Palm Fruits and other Natural Fibres for use in Reinforced Cement Composites. Proc. Inc. RILEM Sym. Sept. 17-21, Salvador, Bahlia, Brazil.

Dahunsi, B. I. O., 2000. The Properties and Potential Applications of Ratton Canes as Reinforcement Material in Concrete. Unpublished Ph.D. Thesis, Department of Agric. Engineering, University of Ibadan P. 289.

Mattone, R., 1990. Comparison between Gypsum Panels Reinforced with Vegetable Fibre. Proc. $2^{\text {nd }}$ Intl. RILEM Sym. Sept. 17-21, Salvador, Bahia, Brazil.

Ndububa, E. E., 2000. Flexural Strength of Mortars Stabilized with Vegetable Fibres at Low-cost Materials for Farm Structures. Journal of Agric. Engineering and Technology 8, 21-25. 